\title{
Investigating L2 Learners' Writing Self-efficacy as a Complex Dynamic System
}

\author{
Sana Almutlaq (Corresponding author) \\ College of Language and Translation, Al-Imam Mohammad ibn Saud Islamic University \\ Riyadh PO Box 5701, Saudi Arabia \\ E-mail: salmutlaq@imamu.edu.sa
}

\author{
Siân Etherington \\ School of Arts and Media, University of Salford \\ Crescent House, Greater Manchester M5 4WT, United Kingdom \\ E-mail: s.etherington@ @alford.ac.uk
}

Received: April 27, 2018 Accepted: May 16, 2018 Published: May 20, 2018

doi:10.5296/ijele.v6i1.13163 URL: https://doi.org/10.5296/ijele.v6i1. 13163

\begin{abstract}
There has been a growing interest in SLA in studying second language (L2) writing development and change from a complex perspective, taking into consideration the full combination of learning processes, learners and contexts of learning. Thus, the research reported here applies a Dynamic Systems Theory (DST) approach to investigate L2 writers' sense of self-efficacy. Although self-efficacy is usually viewed as task-specific, and therefore measured in relation to specific situations, such an approach tends to lead to the production of cross-sectional research looking at one time and one context only. This study moves instead to consider L2 writing self-efficacy as a complex dynamic system that evolves in response to the environment as well as internal re-organisation. Changes in L2 learners' writing self-efficacy were traced over a six-week period through the use of writing self-efficacy questionnaires and introspective journals. Results suggest that L2 writing self-efficacy is best perceived as a dynamic, rather than a fixed, construct, and as complex rather than one-dimensional. Students' perception of their abilities to write is changeable, decentralised, open to influences from the environment and from other external factors, displays non-linear development and tends to settle down in attractor states.
\end{abstract}

Keywords: Dynamic systems theory, complex system, second language writing self-efficacy, language development, non-linear development, attractor states 


\section{Introduction}

Second Language (L2) writing is a complex system that emerges from interaction between several factors. Writing results not merely from composition and development of ideas, but also through presenting these ideas within appropriate discourse and genre conventions, in meaningful sentences, and utilising proper grammar, spelling and punctuation. For L2 writers there is the additional task of familiarising themselves with L2 cultural and social norms. Writing, thus, necessitates dynamic use of a wide array of language subsystems and a complex set of cultural and social factors (Richards \& Renandya, 2002). Regardless of its complexity, writing has been approached in the Second Language Acquisition (SLA) literature from different perspectives, where attention has been drawn to either the contexts in which the learners write, the texts they produce or the processes of writing learners undergo (De Larios, Murphy \& Marin, 2002; Barkaoui, 2007). Although such traditional approaches have led to valuable and instructive insights, they fail to appreciate the complexity of L2 writing or to present a fuller picture of how L2 learners develop their writing abilities and skills. Kramsch (2011) contends that what L2 writers write cannot be attributed to one sole variable, and that students' writing is best understood as emerging from interactions between several factors, including the context.

The last few years have witnessed a growing interest in studying L2 writing development from a Dynamic System Theory (DST) perspective. This change in L2 writing research mirrors changes in the broader context of SLA, now preferably referred to as Second Language Development (SLD). Larsen-Freeman (2014) argues that "Such a perspective rejects the commodification of language implied by the term 'acquisition', instead imbuing language with a more dynamic quality, implied by the term 'development', because it sees language as an ever-developing resource" (p. 491). Research from within such an approach focuses on a 'person-in-context' relational view of writing development and change. Ushioda $(2009,2015)$ explains that this approach aims to study the interaction between individual learners who possess feelings, having their own identities, personalities with unique history and learning background, who have motivation, goals and dreams to achieve, and the context where they study and where they are embedded. Writers' attitudes, values, culture, beliefs and contexts are seen as learning resources, that writers draw upon when they write, and not as obstacles in their learning development (Morton, Storch \& Thompson, 2015).

DST does not aim for generalisation. Rather, it values individual variations, as no two learners are likely to develop in the exact same way (Verspoor, 2015). Dynamic researchers trace individual trajectories to explain the ups and downs in the learning journey. The focus is on change, when, how and what triggers that change. The ultimate result of this changing system is not predictable, even when its elements and their interactions are known. Thus, the utilisation of statistical methods to predict, explain or establish a direct and linear cause-and-effect relationship between studied variables is not favoured within a DST theoretical framework. Studying a variable by isolating it, rather than considering the whole system, only simplifies the reality rather than helps to understand its interconnectedness. A system is seen as more than the sum of its components (Larsen-Freeman, 2015). 
A Dynamic System is also an open and flowing system: influences can come from both inside and outside the system, with no end point known for the system. However, regardless of its dynamicity, the system attempts to settle down into an attractor state (Hiver, 2015). It then remains there and does not move unless a change forces it to.

Although a DST informed approach has been proposed for some time, experimental studies of this kind remain relatively scarce in SLA in general and in L2 writing research in particular. In an attempt to address this gap, the present study considers one aspect of the complexity of L2 writing: the role of writing self-efficacy in learners' writing development.

Self-efficacy is identified by Bandura (1989) as the most influential belief that can impact individual's performance. Although it has been widely researched in the SLA literature and found to be a predictor of success and a motivator for persistence (Mills, 2014), it has received little attention in the field of L2 writing. Furthermore, where L2 writing self-efficacy research exists, this tends to be cross-sectional in nature, looking at one time and one context only. Therefore, this study aims to supplement this area in the literature through a mixed methods and longitudinal investigation of the dynamicity and complexity of students' L2 writing self-efficacy.

\section{Literature Review}

\subsection{Self-efficacy in Psychology}

Self-efficacy is at the centre of Bandura's social cognitive theory, as he indicates that among several thoughts that can influence behaviour, people's beliefs in their capabilities to master desirable actions are the most crucial and pervasive (Bandura, 1989). Such beliefs about self-efficacy stem from various sources: mastery experiences, vicarious experiences, verbal persuasion, and psychological states (Bandura, 1977). Firstly, when individuals succeed in doing a certain task, their confidence in their abilities is boosted. When they fail in doing the task, on the other hand, they feel less efficient and doubt their abilities. Since such feeling is based on real experience, mastering experience is believed to be the most efficient method of making one's sense of self-efficacy robust (Bandura, 1989). Secondly, observing peers' successful performance enhances beliefs in the ability to succeed in a similar task. When watching friends overcome barriers and succeed, one believes he can do it too. Thirdly, individuals who receive praise and positive feedback develop better senses of self-efficacy than those who receive negative feedback and criticism. Finally, states, such as anxiety and depression, can influence people's perception of their ability to perform tasks. Stressed and anxious individuals who doubt their capabilities may disengage very quickly at the first sign of difficulties.

People's judgment of their abilities, or their sense of self-efficacy, influences four psychological processes, namely, the cognitive, motivational, affective and selection processes (Bandura, 1994). First, what people think of themselves can affect their cognitive processes, as it can influence their goal setting and shape their future visualisations. Second, self-efficacious people have high level of motivation. Success, in fact, does not depend on skills only; it 
requires motivation that prompts one to use such skills and knowledge. Third, people's beliefs in their capabilities have an impact on the level of stress and anxiety they experience in threatening situations. Finally, self-efficacy beliefs can influence people's choices of what they want to do and the way to do them. People approach situations they believe they can handle and succeed in and avoid situations that they perceive as beyond their control.

It is important to note that self-efficacy is task-specific and varies from one task to another (Bandura, 1989). It is also sensitive to the environmental context (Pajares, 2003). Thus, the next section reviews studies on self-efficacy in relation to L2 writing.

\subsection{Self-efficacy and L2 Writing}

In the context of L2 learning, self-efficacy is defined as the "beliefs that one has the resources (a) in general, to learn a foreign language and reach a desired level of foreign language proficiency, and (b) more specifically, to perform foreign language related tasks successfully" (Piniel \& Csizér, 2013, p. 526). L2 researchers have investigated self-efficacy in relation to different variables such as achievement, L2 motivation, foreign language anxiety and language learning strategies (Mills, 2014). Most of these studies were correlational in nature and carried out using quantitative methods (Raoofi, Tan \& Chan, 2012).

L2 writing self-efficacy, thus, can be defined as the students' perception of their L2 writing skills and their ability to perform certain L2 writing tasks. Writing self-efficacy beliefs have been studied to establish a cause-and-effect relationship with both L1 and L2 writing development (Nicolaidou, 2012; Pajares \& Valiante, 1997; Duke, 2003). Researchers have found writing self-efficacy to consistently predict learners' achievements, in many cases better than even their actual learning abilities (Bandura, 1993) and better than other affective variables (Raoofi et al., 2012; Mills, 2014; Pajares, 2003).

Writing self-efficacy is also reported as a strong predictor of writing achievement within Pajares and his associates' research in the L1 writing field. Pajares and Johnson (1996), for example, indicate that writing self-efficacy has a direct link to high school students' achievement as measured by their writing-essay performance. These results are also confirmed in later studies of students in other grades, (Pajares \& Valient, 1997; Pajares, Miller \& Johnson, 1999). It is noticeable however, that although there is a considerable body of literature on L1 writing self-efficacy, little is evident in the field of L2 writing.

Within the SLA literature, Abdel-Latif's work (2015) exploring the primary factors which construct L2 writing self-efficacy is key. Results echo those found in the general psychological literature; writing accomplishment, previous writing experience and feedback from others were found to be the main components of L2 writing self-efficacy. In addition, self-efficacy was found to affect students' cognitive and motivational behaviour. Self-efficacious students in this study were reported to achieve high grades in writing and perceived their writing development as improving and their learning experience as successful. Less efficacious learners received low grades and perceived their writing learning experience as unsatisfactory as little, if any, improvement was perceived in their writing skills. Those students tended to evaluate their capabilities based on the feedback they received from others, especially their 
teachers and peers.

Similarly, L2 students in Öztürk and Saydam's study (2014) pinpointed their English level and writing competence (mastery experience), teachers' instruction and feedback as crucial factors building their L2 writing self-efficacy. Among these factors, level of English proficiency was found to play a crucial part: a good command of English boosts students' confidence in their ability to write and use language to express their ideas clearly.

Further research indicates that the relationship between writing self-efficacy and performance is bidirectional: successful performance increases self-efficacy, and strong self-efficacy leads to successful performance, which in turn boosts self-efficacy. Sanders-Reio et al. (2014) found that L2 writing self-efficacy affected students' motivation to write and ultimately enhanced their writing experience. Students with high self-efficacy were reported to enjoy writing more, had low writing apprehension and outperformed their low self-efficacy counterparts.

In contrast, low L2 writing self-efficacy derives from anxiety (Öztürk \& Saydam, 2014). When students' anxiety level rose, their writing self-efficacy declined to a moderate level. L2 writing anxiety is thought to predict L2 writing self-efficacy, with a negative correlation found between these two variables (Salem \& Al Dyiar, 2014). Individuals are believed to expect success when they feel less anxious and stressed (Bandura, 1977).

Constructive teacher feedback is another source of students' confidence in their L2 writing abilities. Writing self-efficacy was found to increase more in L2 students who received systematic feedback from their teachers than in those who received feedback from their peers (Ruegg, 2014). Increased exposure to feedback from individuals who were believed to possess more knowledge and understanding was argued to increase self-efficacy.

Thus, L2 writing self-efficacy is arguably best perceived as a complex construct that emerges from different components such as anxiety and motivation, and these components are both causes and effects of self-efficacy. The L2 writing self-efficacy components are interdependent and the interaction between them can take different directions as the system is decentralised; no single factor has control over others. It follows that approaching L2 writing self-efficacy from a linear cause-and-effect perspective to segregate predetermined variables and isolate them from their contexts may misrepresent the real complexity of L2 writing self-efficacy. The following section discusses the traditional approaches to researching L2 writing self-efficacy and their failure to fully acknowledge the complexity of this construct.

\subsection{Traditional Methodological Approaches to L2 Writing Self-efficacy}

Mainstream research approaches seek to determine the cause-and-effect relationships between writing self-efficacy and other variables, using statistical procedures and then generalise findings to a larger population. In such studies, self-efficacy is modelled as stable and measured at one time, a stance which contradicts Bandura's initial conceptualisation as task-specific (1989). These cross-sectional and co-relational approaches to methodology usually research writing self-efficacy through the use of self-report scales. Bandura (2006) argues that to increase predictiveness, scales must be designed to measure the specific characteristics of a domain of interest. Within self-efficacy scales questions such as "How 
sure are you that you can..." and "How confident are you that you will..." are very common (Zajacova, Lynch \& Espenshade, 2005). Participants report their degree of assurance in their capabilities to perform a delegated task on scales ranging from "not at all confident" to "extremely confident" or "I can do it very well" to "I cannot do it at all" or to choose from 0 to 100 where 0 means not confident at all and 100 means very confident (Zajacova et al., 2005; Wang, 2004).

However, in response to 'the dynamic turn' in SLA research (Larsen-Freeman \& Cameron, 2008; Dörnyei et al., 2015) researchers have shown a growing interest in the complex multidirectional interaction among learner factors, the context and other variables. Applying such a holistic view allows researchers to approach old questions from new perspectives. Such an approach is taken by Piniel and Csizér (2015) in their study of L2 writing self-efficacy as a complex dynamic system. They explored changes in students' L2 writing self-efficacy, anxiety and motivation throughout their fourteen-week academic writing course. Data were gathered longitudinally using questionnaires and a written short essay at the end of the term. Results indicated that L2 writing self-efficacy, motivation and anxiety fluctuated over the course and their developments showed different trajectories. The authors contend that DST offers an alternative perspective allowing an investigation of self-efficacy, anxiety and motivation as complex dynamic subsystems within the learner's own system. They conclude that further research from a similar perspective is needed to shed more lights on such complexity. It is this gap which the present study aims to fill.

\section{Research Methodology}

This study uses a DST informed approach to investigate the complexity and dynamicity of L2 writing self-efficacy development among Saudi ESL learners using mixed methods research tools, both questionnaires and written journals, over a longitudinal timeframe. This paper represents findings from the initial stages of a wider study.

\subsection{Participants}

The research participants were three Saudi L2 learners within a UK private English language institution. They planned to improve their English language level and then to pursue higher education degrees within the university sector. Such a small number of participants is common in studies implementing DST, due to the extensive data collection and analysis involved and the concern to represent the full sense of individual experience (Mercer, 2015; Hiver, 2015; Nitta \& Baba, 2015).

Participants in this research were all females and their age ranged from 25 to 30 . Their mother tongue was Arabic and they all had been in the UK for less than a year at the time of the study. Their level of English was intermediate, equal to IELTS band scores 4 and 5 .

The curriculum at the English institution was fairly intensive. Students took between 20 and 25 hours of instruction a week, including lessons in pronunciation, presentation skills, social English and vocabulary, in addition to the four basic English skills of writing, reading, 
listening and speaking. Students were also encouraged to take part in after-school activities such as visits to museums to familiarise themselves with English culture and history.

Participants were attending the same class, at a similar level of proficiency, were taught by the same instructors, and were assigned the same homework. This unified research setting allows for the illumination of contextual influences on participants' development and change (Piniel \& Csizér, 2015).

\subsection{Instruments}

The study utilised a combination of quantitative and qualitative research tools: a L2 writing self-efficacy scale and descriptive essay written by participants. The L2 writing self-efficacy scale was designed by adapting items from the scale used by Pajares and Valiante (2001) and adding further items (see Appendix A). Unlike other scales designed to assess students' confidence in possessing certain writing skills, such as the ability to spell words correctly or punctuate a paragraph correctly (e.g., Öztürka \& Saydam, 2014); assess learners' confidence in their ability to perform writing tasks, such as writing an argumentative essay or writing a short story (e.g., Pajares \& Johnson, 1994),; or measure learners' confidence in achieving particular grades in their writing classes (e.g., Pajares, Britner \& Valiante, 2000), this scale aimed to measure participants' perceptions of their writing capability in all these three areas. All the 14 items in this scale were designed using the auxiliary verb "can" since self-efficacy measurements assess students' beliefs in their capabilities above all else (Bandura, 1997, 2006).

Participants answered on a scale from 0 to 100, where 0 is "Not confident at all" and 100 is "Completely confident". Bandura (2006) suggests using a 0-100 scale rather than a 4- or 5-point Likert scale, because using very limited options narrows down the variations among individuals. By contrast, adding more scale points, such as a 0-100 scale, enables the collection of more differentiating data and thus proves more reliable as it reflects reality more precisely (Bandura, 1997). This approach is empirically supported by Pajares, Hartley and Valiante (2001), who report that a scale of 0-100 is psychometrically stronger and more predictive than the traditional Likert scale. In addition, it was believed that it would be easier for Saudi students to evaluate themselves on a scale from 0 to 100 , which is similar to their school grading system, than to use vague expressions such as "I am possibly able to do it" and "I am basically and in principle able to do it".

Additionally, participants were asked to write a short descriptive journal entry of 150 words (see Appendix B). They were asked to refer to their general attitude towards L2 writing, how it has changed over time, what made them feel confident and what made them panic when writing in English. They were encouraged to give specific examples to explain their answers. Participants were given the option to write either in English or in their mother tongue, Arabic, to ensure that they expressed themselves accurately and that their English writing skills would not stand as barriers to communicating their ideas. All participants chose to write in Arabic.

The use of introspective journals as a means for data collection allows participants to 


\section{MInstitute ${ }_{\text {Mnk }}^{\text {Macrothink }}$}

thoroughly express their insights, attitudes and beliefs about the topic. It is a direct route to participants' intuitions and feelings (Hatch, 2002). Such writing can also provide evidence of participants' fluctuations in emotions, attitudes and beliefs, thus making it suitable for researching dynamic systems, as frequent writing can capture a range of changes.

Translation of research instruments was used to ensure that participants respond based on fuller understanding and they give reliable answers. Failing to translate properly could threaten both the validity and reliability of the study. Translation was carried out by five translators who were fluent in both Arabic and English. The translation went through five stages as suggested by Dörnyei and Taguchi (2010), translation, review, adjudication, pretesting and finally documentation. Standard Arabic was used to enable an optimal level of understanding and ease for participants (Khalaila, 2013).

\subsection{Data Collection Procedure}

Data was collected three times over a six-week period. Each time participants were asked to complete the questionnaire and write their journals before doing their writing assignments. Writing self-efficacy in this case is measured before students write, as the scale is intended to measure their perceptions of their ability to write in relation to a specific task demand. It took only five to ten minutes to complete each questionnaire and approximately 15 minutes to write the journal entry. Informed consent was obtained from each participant prior to her participation. Subjects were assured that their participation was voluntary and that they could leave the study at any time without consequences. They were also assured that all data would be anonymised.

This approach to data collection is in line with work in a DST theoretical framework. It is longitudinal rather than cross-sectional. Collecting data at different points of time using multiple methods will allow the researchers to capture the multi facets of dynamic change in participants' performance and to understand more fully L2 writing self-efficacy complexity.

\section{Results and Discussion}

\subsection{Results from Quantitative Data}

Each time participants completed the L2 writing self-efficacy scale, they evaluated their perception of their writing ability on scale from 0 to 100 . The scores of the scale range from 0 to 1400 where the higher the score, the higher the confidence. However, after analysing data it appeared that the actual range of L2 writing self-efficacy scale scores displayed by participants was from 940 to 1267 . These Saudi L2 writers seemed to display a relatively high level of writing self-efficacy over a six-week period, see Table 1 below. 
Table 1. Participant's Writing Self-Efficacy Scores

\begin{tabular}{llll}
\hline Participants* & Time. 1 & Time. 2 & Time. 3 \\
\hline Shan & 940 & 1020 & 1070 \\
Jasmen & 1005 & 1025 & 1060 \\
Diana & 1202 & 1233 & 1267 \\
\hline
\end{tabular}

* Pseudonyms were used to protect participants' privacy.

Quantitative data revealed that students' L2 writing self-efficacy increased toward the end of the term. There was a steady growth in students' perception of their abilities to write in English throughout the whole period, as shown in the table 1 above. Despite this general finding, that all participants improved, there were variations in their developmental trajectories. Shan, for example, increased the most, and Jasmen the least. In addition, Shan's biggest increase occurred between time 1 and time 2, while for Jasmen and Diana it occurred between time 2 and time 3. This shows that no two participants developed their L2 writing self-efficacy in the same exact way. L2 writing self-efficacy is found to be a dynamic construct that changes within the same person and changes, also, from one person to another. It is not a trait that remains stable over time, rather it evolves as it adapts to changes in the learning environment and changes in other variables, which will be shown later when discussing the qualitative data. Figure 1 below shows each participant's trajectory.

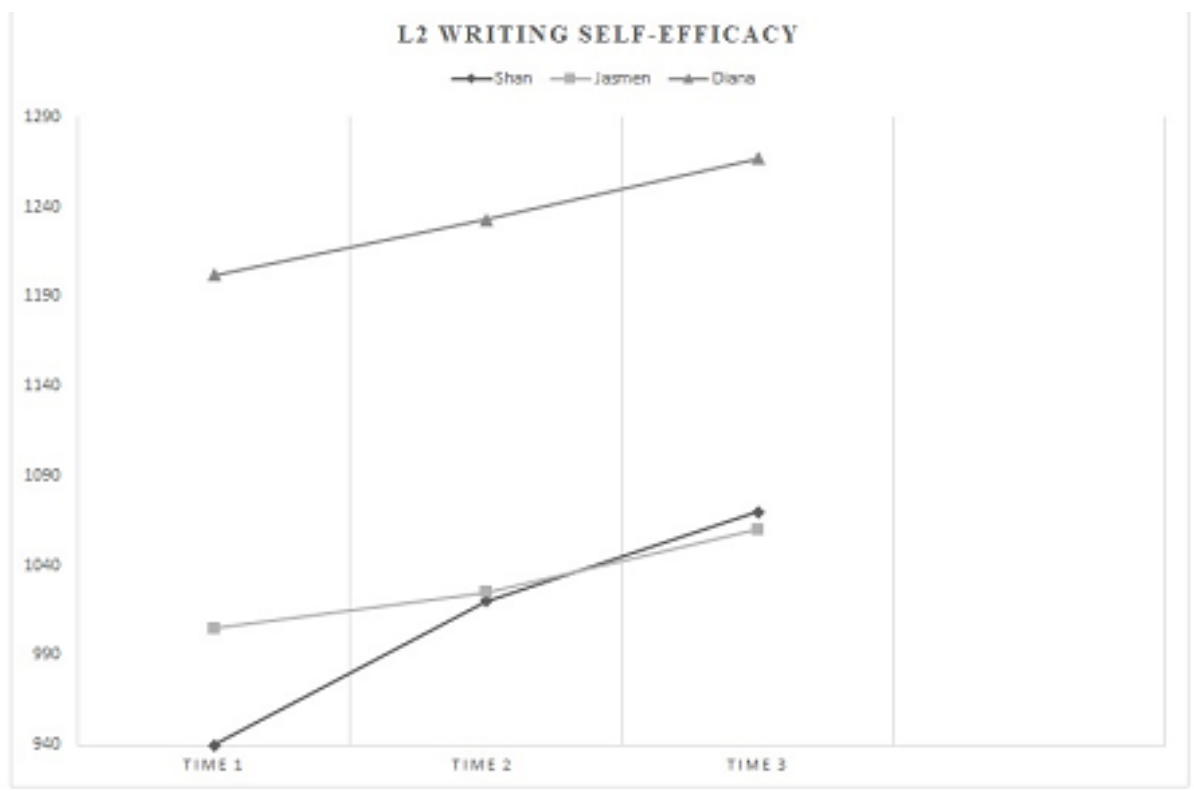

Figure 1. Participants’ L2 Writing Self-Efficacy Trajectories 


\section{Macrothink

\subsection{Results from Qualitative Data}

Results from analysis of the participants' journals provide evidence that L2 writing self-efficacy can be justifiably considered a complex dynamic system. It is changeable, complex, unpredictable, developing in non-linear patterns. The qualitative data analysis below shows how L2 writing self-efficacy appears to fit within the characteristics of a complex dynamic system.

\subsubsection{L2 Writing Self-efficacy is Dynamic}

Data from participants' journals shows writing self-efficacy as a dynamic construct that changes and evolves over time. Larsen-Freeman and Cameron (2008) define a dynamic system as "one that changes with time, and whose future state depends in some way on its present state" (p. 29). The system may depend on its past states, but it is not totally determined by them and cannot be predicted.

When Shan begun studying English around a year ago, she described her writing self-efficacy as very low, she did not even trust her ability to write few words. She said:

When I first started writing in English I did not believe I could write...I could not write well. I even got panicked even when I had to write just one line. (Shan Journal 1)

Writing was a stressful learning experience for her. She was so anxious that she was not able to write at all. However, she practised and worked hard to improve her writing, because she was extrinsically motivated. Writing was important for her academic success. She described herself as extrinsically motivated, but with low writing self-efficacy:

Although my writing was poor I never stop writing. Not because I love writing but because I believe in its importance to my future studies. (Shan Journal 1)

After around a year of studying, her writing had improved which was reflected in her confidence as a L2 writer. She explained:

I can easily write essays with 300 words. I still commit some mistakes but my ideas are clear and connected and I am happy about it. (Shan Journal 3)

Shan's writing self-efficacy had changed, moving from believing in her incapability to write one line to have confidence in writing long essays. Although she admitted making mistakes, she was happy with the overall accomplishment, paying no attention to details. 
Jasmen's entry showed another example of changing and dynamic writing self-efficacy. Jasmen described her writing self-efficacy when she started to learn English as very low. She explained:

Eight months ago, I could not write at all even a short paragraph. Writing requires correct usage of grammar which was so hard for me as a beginner. (Jasmen Journal 1)

Later, she expressed her disappointment that even after some time studying abroad, her writing was not improving to the level she desired. She was only capable of doing basic tasks. She wrote:

I can only write about certain topics and I only write simple sentences. (Jasmen Journal 1)

However, in her third entry her self-efficacy had changed after some successful writing classes. She wrote two essays 300 words each. They were about new topics and she wrote them properly. She commented on this achievement saying:

I am happy and I feel so confident in my ability to write. (Jasmen Journal 3)

Her teacher noticed the progress and acknowledged it. She added:

I am so happy because my writing teacher praised my work. She said that my writing is improving and now I will work hard to live up to her expectations. (Jasmen Journal 3)

Teacher's positive feedback played a crucial role in persuading her that she was capable of writing in English and thus enhanced and changed her writing self-efficacy. This result is in line with those found in literature (e.g., Öztürk \& Saydam, 2014).

Participant Diana's writing self-efficacy changed over time. She started learning with a low writing self-efficacy. Writing was not easy for her as she explained:

I was not able to write. I did not like to write. I only wrote short paragraphs about myself. (Diana Journal 1)

After a period of formal studying, she felt able to write on different topics, so her writing self-efficacy increased. She wrote: 
Now I am sure I can write in different topics. I learnt new vocabulary and can use them in sentences using simple structure and correct grammar. (Diana Journal 2)

All participants started their L2 writing journey with very low self-efficacy where they expressed their concerns about their deficiency even in regard to writing a simple sentence about a simple topic. However, toward the end, participants' writing self-efficacy had increased as they believed they were capable of writing long essays in different genres. These findings may pose serious questions for research that tends to reflect on snapshots of individual self-efficacy in one particular time and then generalise their results, assuming the stability of self-efficacy beliefs.

\subsubsection{L2 Writing Self-efficacy is Decentralised}

Writing self-efficacy is a complex multifaceted construct. In each example, it is composed of a range of factors, relating to each participants' understanding of what makes good writing, that make up the system. Participants chose to focus on different aspects of language learning and, thus, their systems self-organised to display different paths or trajectories of development. There is no single power or variable that leads to change participants' perceptions of their confidence to write. Participant Shan's writing self-efficacy, for example, improved with practice. She believed that practice makes perfect, so the more she practiced, the more confident she became in her writing abilities. She explained:

Due to practice, I believe my writing is now improved. I can easily write essays with 300 words. I still committed some mistakes but my ideas are clear and connected and I am happy about it. (Shan Journal 3)

It is interesting to notice that in her second journal entry she was concerned about making mistakes and linked this to her writing self-efficacy; she stated that she could not write because she would make mistakes. However, in her third entry, she stated clearly that she knew she made mistakes, but she felt confident. Her confidence in her writing ability was re-organised to adapt to change in her practice. She was exposed to tasks with high level of complexity in which she wrote 300 words in different genres; thus, her self-efficacy evolved.

Jasmen, on the other hand, related writing abilities to good use of grammar. Her self-efficacy improved when she wrote essays with good grammar. She wrote:

I could not write at all.... Writing requires correct usage of grammar which was so hard for me as a beginner. (Jasmen Journal 1)

Eight months later, she feels shameful that she is still committing grammar and spelling 
mistakes when writing. She seems to focus on grammatical accuracy as a criterion of good writing, with the consequence that, although she managed to express her ideas and opinions about different topics clearly, she was not satisfied. She adds:

I can only write about certain topics and I only write simple sentences. It is a shame that I keep making a lot of grammar and spelling mistakes at this stage. (Jasmen Journal 1)

She only felt confident when she wrote perfectly and her teacher praised her work. She added:

I am so happy because my writing teacher praised my work. She said that my writing is improving. (Jasmen Journal 3)

Jasmen's writing self-efficacy developed as it adapted to changes in her grammatical accuracy levels. Her confidence was low when her grammar was poor; as soon as her grammar advanced, her self-efficacy re-organised and became stronger.

Diana paid particular attention to her ability to use L2 to write about different topics. She did not felt efficacious when she was able to write only about herself, but her self-efficacy adapted and improved when she successfully wrote about different topics. She wrote:

\section{Now I am sure I can write in different topics. (Diana Journal 2)}

Thus, it is clear that L2 writing self-efficacy is not a monolithic construct. For each participant, it emerged from different components, based on participants' understandings of good writing, working together to organise, and re-organise, their senses of writing ability.

\subsubsection{L2 Writing Self-efficacy is an Open System}

L2 writing self-efficacy system is open to influence and be influenced by environmental factors, such classroom performance, teacher feedback, and other cognitive and affective factors, such as achievement and anxiety. Participant Shan, for example, pointed out earlier that her low self-efficacy caused anxiety and stressed her to the extent that she could not write even a single sentence. In this case, her writing self-efficacy led to failure to write and a stressful writing experience. This finding supports others in literature that self-efficacy and anxiety are related (Salem \& Al Dyiar 2014; Öztürk \& Saydam, 2014) but what is stressed here is that such a relationship is not a simple direct cause and effect. Rather, it is a complex multi-directional relationship where writing self-efficacy can be the cause and the effect.

Shan also linked such feeling of self-deficiency in writing to her poor writing skills, which accords with Öztürk and Saydam's findings (2014) that students' perceptions of their linguistic knowledge have impact on their writing self-efficacy. Shan explained: 
I know I cannot write because I will make a great deal of spelling mistakes, repetition and will use limited number of words. (Shan Journal

2)

Fearing of failure is a characteristic of perfectionists. She did not want to write because she did not tolerate making mistakes. She did not trust her ability as a L2 writer and this kept her from writing. Shan's writing self-efficacy can be argued to be an open system that is influenced by her understanding of the nature of L2 writing, linguistic knowledge, and her fear of making mistakes, and influences her anxiety.

Jasmen's writing self-efficacy is open to be influenced by other sets of variables. Social persuasion is one of them. She was praised by her teacher in front of the whole class, which strongly influenced her writing self-efficacy. This indicates agreement with Bandura's claim that individuals who perceive and accept praise and positive feedback develop a good sense of self-efficacy (Bandura, 1977). The teacher persuaded her to believe that she was capable of writing in L2, which had an impact on her perception of writing self-efficacy. Successful accomplishment is another factor. When she successfully wrote two long essays, she felt more confident in her L2 writing ability.

Diana's writing self-efficacy is also open to interconnection with her level of proficiency and her successful learning experiences. She felt more confident in her ability to write when she wrote using new grammatical features and new structure. She commented:

What makes me feel confident in my ability to write this week is when I wrote using new structure or grammar. Another reason that boosts my confidence is when I found a mistake in my teacher correction (Diana journal 3).

Finding a mistake in the native English speaker teacher's correction had a major impact on her writing confidence.

A further successful learning experience seemed to influence Diana's sense of self-efficacy. She wrote in her third entry:

After a 10-week-IELTS course, I feel I can write well and I will pass my next exam with a good grade. We are lucky this course because our teacher is encouraging and supportive. We even wrote email letters to her to practice our writing skills. (Diana Journal 3)

Having a supportive and encouraging teacher appeared to be of great importance to her self-efficacy. She wrote about a past experience when she lost her confidence in her ability to write due to her teacher negativity. She explained: 
She did not believe in me. She made fun of my ideas and thought they were inappropriate to my level of English. Instead of encouraging me and appreciating my efforts, she made me feel worse and worse. (Diana journal 3)

We can conclude that writing self-efficacy is an open system that interacts with a wide range of variables ranging from teacher's feedback to writing achievement. Although those students share the same learning experience, each student's writing self-efficacy is a unique system that interacts with a different set of factors that are perceived by students as of greater or lesser importance to their sense of efficacy at one time.

\subsubsection{L2 Writing Self-efficacy is Non-linear}

Writing self-efficacy development is not predictable. Cause and effects relationships do not apply to dynamic changes of writing self-efficacy. Participant Shan, for example, felt effective as a writer, although she was still making a great deal of mistakes. She was aware of her limitations, but her sense of self-efficacy improved. She said:

I still committed some mistakes, but my ideas are clear and connected and I am happy about it. (Shan Journal 3)

This suggests that there is no linear relationship between reduction in mistakes and self-efficacy. L2 writing is more complex than that. Other factors came into play, such as her success in writing 300-word essays or her ability to express her ideas and thoughts. Thus, taking one variable, such as errors, and studying its impact on writing self-efficacy may keep us from seeing the overall picture.

Similarly, participant Diana was worried about her IELTS test, but she nevertheless felt confident that she would pass with a good grade. Her anxiety did not seem to influence her self-efficacy. She was so optimistic. She wrote:

I am worried about my next IELTS writing test but I feel so confident in my ability to get a high grade. I have practised a lot and I can write now part 1 and part 2 so easily. In order to get a good grade, I will use simple and clear sentence structure and grammar. If I get a good grade my confidence will be raised and I will be encouraged to write more and more.

(Diana Journal 2)

Diana, as shown earlier, was concerned about writing on different topics. So since she practised writing about IELTS topics and practised doing part 1 and 2, her writing self-efficacy was kept up regardless of her anxiety. In addition, Diana's self-awareness about 
how self-confidence is influenced by outcomes and how this in turn will influence her writing is an important part of her positive attitude and growing sense of self-efficacy and development. Without being aware of these links she might not have been able develop her confidence to write in the same way.

Writing self-efficacy interactions with other variables are not linear and thus the results cannot easily be predicted. Searching for a simple cause-and-effect relationship between variables to determine the beginning and the end of interaction is not applicable to investigate complex systems such as self-efficacy. As shown above, anxiety and awareness of low performance do not always predict low writing self-efficacy.

\subsubsection{L2 Writing Self-efficacy Settles in Attractor States}

Although writing self-efficacy is dynamic, it tends, like other dynamic systems, to settle down in attractor states (Hiver, 2015). Participant Shan's writing self-efficacy behaviour is an example. In her second journal entry, she was reassured of her ability to write due to a successful week of activity. She edited her own work and she was able to identify her mistakes. She explained:

I can edit my own drafts. I corrected my drafts and I was able to find the grammar mistakes. (Shan Journal 2)

Such success seemed to drive her writing self-efficacy to settle in an attractor state so that, although she later faced some disruptions, writing self-efficacy manages to stay high. Among these disruptions was her failure to edit sentences structures, such as her inability to differentiate between structures such as "affect negatively" or "negatively affect" when writing. She also did not think she was able to edit her classmates' drafts. She doubted her abilities to find their mistakes as their level of English was different and they used different and uncommon vocabulary. She added:

I do not think I am the right person to tell what is correct or what is not... it is just too hard for me. (Shan Journal 2)

L2 writing self-efficacy attractor state was affected by her internalised self-image as a second language learner who could edit her work and find her own mistakes, and she was happy with that view. Bandura (1977) indicated that after students' build strong self-efficacy, and internalise it, minor or occasional failures may not have an effect on it at all. Another explanation is that she did not see the lack of ability to correct others as a failure or problem. Correcting others was not something that would help her to improve her writing abilities, so even if she knew she lacked it, it did not affect her writing self-efficacy. She did not feel an urge to develop her abilities to be able to correct her classmates' work.

Shan's third journal entry showed that her confidence in her second language writing ability 
settled in, remaining positive and strong. Such strong confidence influenced the way she interpreted her writing deficiencies. She attributed her spelling mistakes, for example, to her carelessness, and she did not doubt her ability. She commented:

The only reason that my spelling is not improved is because I did not take it seriously. I did not put in much efforts to learn spelling. I believe if I spend some time learning spelling, my mistakes will reduce. I also use computer which corrects my spelling automatically. That is why my spelling is not improving. (Shan Journal 3)

When writing self-efficacy settles down into a typical behaviour, such as strong self-efficacy in Shan's case, it can be disturbed, but it tends to come back to its original position unless a strong force moves the system away from its attractor state.

Data gathered from participants' journals gives support to the claim that second language writing self-efficacy is best perceived as a dynamic construct that is changeable, decentralised, has an open system, non-linear and tends to settle down in attractor states.

\section{Implications for Teaching}

Findings from the study encourage teachers to provide learning environments that create affordances for the emergence of new and desirable levels of writing self-efficacy. The teacher's role is to help students to adapt to changes in the environment and in their learning journey by being flexible and open to the different ways in which students progress. Therefore, teachers are advised to provide their students with learning materials differentiated for difficulty in order to support them in adapting to changes.

Instruction does not necessary lead to learning. Instead students choose to respond to different affordances found in the learning environment and thus they develop differently making their own unique trajectories. Writing teachers are encouraged to provide students with rich materials and expose them to various learning affordances, so they have the chance to interact with environment and learn. Successful learning experiences can boost their confidence and ultimately enhance their writing achievement.

Feedback from teachers play a crucial role in directing students' self-efficacy toward or away from a particular behaviour. L2 teachers' praise of students' writing achievement may shift their confidence towards strong beliefs in their ability to write in L2 and minimise the effect of doubts and drawbacks on their performance. Negative feedback, on the contrary, may deepen students' beliefs in their incapability and dragged them into a state of despair.

\section{Conclusion}

This study aimed to investigate L2 writing self-efficacy as a complex dynamic system. It 
illustrates how a longitudinal, more open methodological approach to L2 writing self-efficacy research is able to provide a deeper and more complex picture. Elements of a DST informed view of this area are apparent in the findings and raise serious questions about traditional approaches to conceptualising and researching L2 writing self-efficacy. Thus, this work opens new avenues for understanding L2 writing self-efficacy as a complex dynamic evolving construct. This, in turn, will broaden out approaches to L2 writing development research and influences on L2 writing performance and attainment.

\section{Notes}

This study was part of a larger study that was supported by Al-Imam Mohammad ibn Saud Islamic University, Riyadh, Kingdom of Saudi Arabia [ST/00383904]

\section{References}

Abdel-Latif, M. M. (2015). Sources of L2 writing apprehension: a study of Egyptian university students. Journal of Research in Reading, 38(2), 194-212. https://doi.org/10.1111/j.1467-9817.2012.01549.x.

Bandura, A. (1977). Self-efficacy: toward a unifying theory of behavioural change. Psychological review, 84(2), 191-215 https://doi.org/10.1037/0033-295X.84.2.191

Bandura, A. (1989). Social cognitive theory. In R. Vasta (Ed.), Annals of child development (Vol. 6, pp. 1-60). Greenwich, CT: JAI Press.

Bandura, A. (1993). Perceived self-efficacy in cognitive development and functioning. Educational psychologist, 28(2), 117-148. https://doi.org/10.1207/s15326985ep2802_3

Bandura, A. (1994). Self-efficacy. In V. S. Ramachaudran (Ed.), Encyclopaedia of human behaviour (Vol. 4, pp. 71-81). New York: Academic Press.

Bandura, A. (2006). Guide for constructing self-efficacy scales. In F. Pajares \& T. Urdan (Eds.), Self-efficacy beliefs of adolescents (pp. 307-337).

Barkaoui, K. (2007). Teaching writing to second language learners: Insights from theory and research. TESL Reporter, 40(1), 35-48.

De Larios, J. R., Murphy, L., \& Marin, J. (2002). A critical examination of L2 writing process research. In S. Ransdell, \& M. Barbier (Eds.), New directions for research in L2 writing (pp. 11-47). Springer Netherlands. https://doi.org/10.1007/978-94-010-0363-6_2

Dörnyei, Z., MacIntyre, P., \& Henry, A. (2015). Motivational dynamics in language learning. Bristol: Multilingual Matters. https://doi.org/10.21832/9781783092574

Dörnyei, Z., \& Taguchi, T. (2010). Questionnaires in second language research: Construction, administration, and processing. Routledge. 


\section{Mll Macrothink}

International Journal of English Language Education

ISSN 2325-0887

2018, Vol. 6, No. 1

Duke, B. L. (2003). The influence of using cognitive strategy instruction through writing rubrics on high school students' writing self-efficacy, achievement goal orientation, perceptions of classroom goal structures, self-regulation, and writing achievement (Doctoral dissertation)

Retrieved

from https://shareok.org/bitstream/handle/11244/676/3109071.PDF?sequence=1\&isAllowed=y

Hatch, J. A. (2002). Doing qualitative research in education settings. SUNY Press.

Hiver, P. (2015). Attractor states. In Z. Dörnyei, P. MacIntyre, \& A. Henry (Eds.), Motivational Dynamics in language Learning (pp. 20-28) Bristol: Multilingual Matters Ltd. https://doi.org/10.21832/9781783092574-005

Khalaila, R. (2013). Translation of Questionnaires into Arabic in Cross-Cultural Research Techniques and Equivalence Issues. Journal of Transcultural Nursing, 24(4), 363-370. https://doi.org/10.1177/1043659613493440

Kramsch, C. (2011). Why is everyone so excited about complexity theory in applied linguistics? Melanges CRAPEL, 2(33), 9-24.

Larsen-Freeman, D. (2014). Saying what we mean: Making a case for "language acquisition" to become "language development." Language Teaching, 48(4), 491-505. https://doi.org/10.1017/s0261444814000019

Larsen-freeman, D. (2015). Ten 'lessons' from complex dynamic systems theory: What is on offer. In Z. Dörnyei, P. MacIntyre, \& A. Henry (Eds.), Motivational Dynamics in language Learning (pp. 11-19). Bristol: Multilingual Matters Ltd. https://doi.org/10.21832/9781783092574-004

Larsen-Freeman, D., \& Cameron, L. (2008). Complex systems and applied linguistics. Oxford University Press. https://doi.org/10.1111/j.1473-4192.2007.00148.x

Mercer, S. (2015). Social network analysis and complex dynamic systems. In Z. Dörnyei, P. MacIntyre, \& A. Henry (Eds.), Motivational Dynamics in language Learning (pp. 73-82) Bristol: Multilingual Matters Ltd. https://doi.org/10.21832/9781783092574-010

Mills, N. A. (2014). Self-efficacy in Second Language Acquisition. In S. Mercer, \& M. Williams (Eds.), Multiple Perspectives on the Self in SLA (pp. 6-22). Bristol: Multilingual Matters. https://doi.org/10.21832/9781783091362-003

Morton, J., Storch, N., \& Thompson, C. (2015). What our students tell us: Perceptions of three multilingual students on their academic writing in first year. Journal of Second Language Writing, 30, 1-13. https://doi.org/10.1016/j.jslw.2015.06.007

Nicolaidou, I. (2012). Can process portfolios affect students' writing self-efficacy? International Journal of Educational Research, 56, 10-22. https://doi.org/10.1016/j.ijer.2012.08.002

Nitta, R., \& Baba, K. (2015). Self-regulation in the evolution of the ideal L2 self: A complex dynamic systems approach to the L2 motivational self system. In Z. Dörnyei, P. MacIntyre, \& 
A. Henry (Eds.), Motivational dynamics in language learning (pp. 374-404). Bristol: Multilingual Matters Ltd. https://doi.org/10.21832/9781783092574-023

Öztürk, G., \& Saydam, D. (2014). Anxiety and self-efficacy in foreign language writing: The case in Turkey. Başkent University Journal of Education, 1(2). 10-21.

Pajares, F. (2003). Self-efficacy beliefs, motivation, and achievement in writing: A review of the literature. Reading \&Writing Quarterly, 19(2), 139-158. https://doi.org/10.1080/10573560308222

Pajares, F., Britner, S. L., \& Valiante, G. (2000). Writing and science achievement goals of middle school students. Contemporary Educational Psychology, 25, 406-422.

Pajares, F., Hartley, J., \& Valiante, G. (2001). Response format in writing self-efficacy assessment: Greater discrimination increases prediction. Measurement and Evaluation in Counseling and Development, 33, 214-221.

Pajares, F., \& Johnson, M. J. (1994). Confidence and competence in writing: The role of self-efficacy, outcome expectancy, and apprehension. Research in the Teaching of English, 313-331.

Pajares, F., \& Johnson, M. J. (1996). Self-efficacy beliefs and the writing performance of entering high school students. Psychology in the Schools, 33(2), 163-175. https://doi.org/10.1002/(sici)1520-6807(199604)33:2\%3C163::aid-pits10\%3E3.0.co;2-c

Pajares, F., Miller, M. D., \& Johnson, M. J. (1999). Gender differences in writing self-beliefs of elementary school students. Journal of Educational Psychology, 91(1), 50-61. https://doi.org/10.1037/0022-0663.91.1.50

Pajares, F., \& Valiante, G. (1997). Influence of self-efficacy on elementary students' writing. The Journal of Educational Research, 90(6), 353-360. https://doi.org/10.1080/00220671.1997.10544593

Pajares, F., \& Valiante, G. (2001). Gender differences in writing motivation and achievement of middle school students: A function of gender orientation? Contemporary Educational Psychology, 26(3), 366-381. https://doi.org/10.1006/ceps.2000.1069

Piniel, K., \& Csizér, K. (2013). L2 motivation, self-efficacy and anxiety: The interrelationship of individual variables in the secondary school context. Studies in Second Language Learning and Teaching, 3, 523-550. https://doi.org/10.14746/ssllt.2013.3.4.5

Piniel, K., \& Csizér, K. (2015). Changes in motivation, anxiety and self-efficacy during the course of academic writing seminar. In Z. Dörnyei, P. MacIntyre, \& A. Henry (Eds.), Motivational dynamics in language learning (pp. 164-194). Bristol: Multilingual Matters. https://doi.org/10.21832/9781783092574-015

Raoofi, S., Tan, B. H., \& Chan, S. H. (2012). Self-efficacy in second/foreign language learning contexts. English Language Teaching, 5(11), 60-73. https://doi.org/10.5539/elt.v5n11p60 


\section{Macrothink}

International Journal of English Language Education

ISSN 2325-0887

2018, Vol. 6, No. 1

Richards, J., \& Renandya, W. (2002). Methodology in Language Teaching: An Anthology of Current Practice. Cambridge University Press: Cambridge. https://doi.org/10.1017/cbo9780511667190

Ruegg, R. (2014). The effect of peer and teacher feedback on changes in EFL students' writing self-efficacy. The Language Learning Journal, 1-18. https://doi.org/10.1080/09571736.2014.958190

Salem, A. A. M., \& Al Dyiar, M. A. (2014). Writing anxiety as a predictor of writing self-efficacy in English for special education Arab learners. International Education Studies, 7(6), 128-134. https://doi.org/10.5539/ies.v7n6p128

Sanders-Reio, J., Alexander, P. A., Reio, T. G., \& Newman, I. (2014). Do students' beliefs about writing relate to their writing self-efficacy, apprehension, and performance? Learning and Instruction, 33, 1-11. https://doi.org/10.1016/j.learninstruc.2014.02.001

Ushioda, E. (2009). A person-in-context relational view of emergent motivation, self and identity. In Z. Dörnyei, \& E. Ushioda (Eds.), Motivation, language identity and the L2

self (pp. 215-228). Bristol: Multilingual Matters. https://doi.org/10.21832/9781847691293-012

Ushioda, E. (2015). Context and complex dynamic systems theory. In Z. Dörnyei, P. MacIntyre, \& A. Henry (Eds.), Motivational dynamics in language learning (pp. 47-54). Bristol: Multilingual Matters. https://doi.org/10.21832/9781783092574-008

Verspoor, M. (2015). Initial conditions. In Z. Dörnyei, P. MacIntyre, \& A. Henry (Eds.), Motivational Dynamics in Language Learning (pp. 38-46). Bristol: Multilingual Matters Ltd. https://doi.org/10.21832/9781783092574-007

Wang, C. (2004). Self-regulated learning strategies and self-efficacy beliefs of children learning English as a second language (Doctoral dissertation). Retrieved from http://citeseerx.ist.psu.edu/viewdoc/download?doi=10.1.1.964.252\&rep=rep1\&type=pdf

Zajacova, A., Lynch, S. M., \& Espenshade, T. J. (2005). Self-efficacy, stress, and academic success in college. Research in Higher Education, 46(6), 677-706. https://doi.org/10.1007/s11162-004-4139-z 


\section{Appendix A L2 writing self-efficacy scale}

On a scale from 0 (not confident at all) to 100 (completely confident), show how confident you feel when you perform the writing tasks necessary for your work. You may use any number between 0 and 100 .

$\begin{array}{lllllllllll}0 & 10 & 20 & 30 & 40 & 50 & 60 & 70 & 80 & 90 & 100\end{array}$

Not confident

Completely

at all

confident

\begin{tabular}{|c|c|}
\hline 1. & I can correctly spell all words in an essay. \\
\hline 2. & I can correctly punctuate an essay. \\
\hline 3. & I can correctly use all parts of speech in an essay. \\
\hline 4. & I can write simple sentences with good grammar. \\
\hline 5 . & I can correctly use singulars and plurals and prepositions and verb tenses \\
\hline 6. & I can write a strong paragraph that has a good topic sentence or main idea. \\
\hline 7. & $\begin{array}{l}\text { I can write paragraphs with details that support the ideas in the topic sentences or } \\
\text { main ideas. }\end{array}$ \\
\hline 8. & I can write a proper conclusion. \\
\hline 9. & $\begin{array}{l}\text { I can write a well-organized and sequenced paper with good introduction, body, } \\
\text { and conclusion. }\end{array}$ \\
\hline 10. & $\begin{array}{l}\text { I can get ideas across in a clear manner by staying focused without getting off the } \\
\text { topic. }\end{array}$ \\
\hline 11. & I can write across different genres with good expressions. \\
\hline 12. & When editing my writing drafts, I can identify my mistakes. \\
\hline 13. & I can edit drafts written by my classmates. \\
\hline 14. & I can get an excellent grade in the next assignment. \\
\hline
\end{tabular}




\section{Appendix B Journal}

Please write a short descriptive essay of 150 words about explaining how confident you are in your ability to write and what makes you comfortable or uncomfortable when you are writing in English. Refer to your general attitude towards writing and how it has changed over time. Please explain your answer with examples.

\section{Copyright Disclaimer}

Copyright for this article is retained by the author(s), with first publication rights granted to the journal.

This is an open-access article distributed under the terms and conditions of the Creative Commons Attribution license (http://creativecommons.org/licenses/by/3.0/). 